\title{
ANALISIS SENTIMEN PADA TWITTER TERHADAP PENGGUNAAN ANTIBIOTIK DI INDONESIA DENGAN NAIVE BAYES CLASSIFIER
}

\section{SENTIMENT ANALYSIS ON TWITTER ABOUT THE USE OF ANTIBIOTICS IN INDONESIA WITH NAIVE BAYES CLASSIFIER}

\author{
Oke Dwiraswati $^{1^{*}}$, Kemal Nazaruddin Siregar ${ }^{2}$ \\ 'Badan Pengawas Obat dan Makanan, Jakarta, Indonesia. \\ ${ }^{2}$ Departemen Biostatistik dan Ilmu Kependudukan, Fakultas Kesehatan Masyarakat, \\ Universitas Indonesia, Depok, Indonesia. \\ email: ${ }^{*}$ okedwiraswati98@gmail.com, ${ }^{2}$ nazarudin.kemal51@gmail.com
}

\begin{abstract}
ABSTRAK
Saat ini, masih ditemukan perilaku yang salah dalam penggunaan antibiotik sehingga menjadi risiko terjadinya resistensi. WHO mencatat angka kematian akibat resistensi antibiotik sampai tahun 2014 sekitar 700.000 orang/tahun dan pada 2050 diperkirakan 10 juta jiwa/tahun. Hal ini terjadi karena kurangnya pengetahuan masyarakat tentang penggunaan antibiotik yang tepat. Untuk mengetahui opini masyarakat tentang penggunaan antibiotik dengan cepat dapat dilakukan analisis sentimen dari media sosial. Melalui media sosial salah satunya Twitter, masyarakat memberikan beragam opini, sehingga dapat dibuat analisis sentimen terhadap penggunaan antibiotik di Indonesia yang diklasifikasikan menjadi 2 kelas yaitu positif dan negatif. Tujuan penelitian ini merancang sistem untuk analisis sentimen terhadap penggunaan antibiotik dari Twitter menggunakan metode pengklasifikasian berbasis machine learning, yaitu Naive Bayes Classifier. Dilakukan serangkaian tahapan yaitu pengumpulan data dari Twitter, preprocessing, proses klasifikasi dengan algoritma Naive Bayes Classifier, dan evaluasi performa. Dari hasil uji dengan 10 -fold cross validation diperoleh nilai rata-rata akurasi $84 \%$ dengan rincian precission $88 \%$, recall $81 \%$ dan $f$-measure $84 \%$ dengan jumlah 200 tweet $(100$ negatif, 100 positif) dibagi ke dalam data latih:data uji $=9: 1$. Disimpulkan bahwa metode Naive Bayes Classifier dapat diterapkan untuk melakukan analisis sentimen terhadap penggunaan antibiotik di Indonesia. Hasil analisis digunakan sebagai pertimbangan dalam menentukan strategi kampanye penggunaan antibiotik yang tepat.
\end{abstract}

Kata Kunci : analisis sentimen, antibiotik, naive bayes classifier, Twitter

\begin{abstract}
At present, wrong behavior is still found in the use of antibiotics, that becoming a risk of resistance. WHO noted that the number of deaths due to antibiotic resistance until 2014 was around 700,000 people/year and in 2050 it is estimated that 10 million people/year. Knowledge and attitude in using antibiotics is an important role in the success of the treatment process. To find out people's opinions about the use of antibiotics quickly can be done through analysis of sentiments from social media. Through social media Twitter, the public can provide a variety of opinions or responses to the use of antibiotics, so that sentiment analysis can be made about the use of antibiotics in Indonesia which supports two basic classes namely positive and negative. This study aims to design a system for the sentiments analysis on the use of antibiotics from Twitter using the machine learning based classification method, namely Naive Bayes Classifier. From a series of stages are carried out, namely data collection from Twitter, preprocessing, the classification process with the Naive Bayes Classifier algorithm, and performance evaluation. The results of the test with 10 -fold cross validation, the average value
\end{abstract}


of accuracy is $84 \%$ with detailed precission $88 \%$, recall $81 \%$ and $f$-measure $84 \%$, with 200 tweets (100 negative, 100 positive) divided into training data:testing data $=9: 1$. It was concluded that the Naive Bayes Classifier method could be applied to analyze sentiment towards antibiotic use in Indonesia. The results of the analysis are used as a consideration in determining the campaign strategy for using the right antibiotics.

Keywords: antibiotics, naïve bayes classifier, sentiment analysis, Twitter

\section{PENDAHULUAN}

Antibiotik adalah obat untuk mencegah dan mengobati infeksi bakteri yang banyak beredar di masyarakat. Saat ini, masih ditemukan perilaku yang salah dalam penggunaan antibiotik sehingga menjadi risiko terjadinya resistensi antibiotik, diantaranya: peresepan antibiotik secara berlebihan oleh tenaga kesehatan; adanya anggapan yang salah di masyarakat bahwa antibiotik merupakan obat dari segala penyakit; dan lalai dalam menyelesaikan treatment antibiotik. ${ }^{(1)}$

World Health Organization (WHO) mencatat angka kematian akibat resistensi antibiotik sebanyak sampai tahun 2014 sekitar 700 . 000 orang per tahun. WHO pun memprediksi, pada 2050 mendatang diperkirakan 10 juta jiwa per tahun. ${ }^{(2)}$ Berdasarkan hasil penelitian BPOM dalam kegiatan Pemetaan Pengelolaan Obat di Fasilitas Pelayanan Kefarmasian, diketahui bahwa sebanyak kurang lebih 83,52\% penyerahan antibiotika di Apotek dilakukan tanpa resep dokter. ${ }^{(3)}$ Resistensi terlihat pada hampir semua antibiotik yang telah dikembangkan dari mulai 1940 hingga 2011. Akibatnya, pada 2015 infeksi bakteri kembali menjadi ancaman. ${ }^{(4)}$

Adanya perilaku yang salah dalam penggunaan antibiotik terjadi karena kurangnya pengetahuan masyarakat tentang penggunaan antibiotik yang tepat. ${ }^{(5)}$ Pengetahuan dan sikap dalam penggunaan antibiotik yang tepat merupakan peran penting dalam keberhasilan proses pengobatan. Untuk mengetahui opini masyarakat tentang penggunaan antibiotik dengan cepat dapat dilakukan melalui analisis sentimen dari media sosial. Melalui media sosial salah satunya Twitter, masyarakat dapat memberikan beragam opini atau respon terhadap penggunaan antibiotik, sehingga dapat dibuat analisis sentimen tentang opini masyarakat terhadap penggunaan antibiotik di Indonesia. Twitter adalah salah satu media sosial terbesar dan paling populer di Amerika Serikat (AS) dan di dunia dengan 310 juta pengguna aktif bulanan dan 500 juta tweet per hari. Batas 140 karakter per-Tweet membuat pengguna memposting lebih singkat dan ekspresif dibandingkan jejaring sosial dan blog lain. Karakteristik ini membuat Twitter menjadi sumber data yang sangat berharga untuk peneliti informatika kesehatan masyarakat. ${ }^{(6)}$

Beberapa peneliti telah menggambarkan kegunaan dari Twitter tentang penyalahgunaan obat. Infodemiologi melalui Twitter juga telah digunakan dalam penelitian yang melacak sentimen dan informasi selama bencana alam, penyalahgunaan antibiotik, serta masalah dan pola kesehatan masyarakat lainnya. ${ }^{(7)}$ Pengawasan media sosial telah membuktikan banyak manfaatnya dalam mengatasi masalah kesehatan masyarakat, seperti perkiraan pola epidemiologi ${ }^{(8)}$ meramalkan wabah penyakit ${ }^{(9)(10)}$, mendeteksi efek samping obat $^{(11)}$, dan menilai vaksinasi. ${ }^{(12)(13)}$

Analisis sentimen atau opinion mining merupakan proses mengekstrak, mengolah dan memahami data tekstual secara otomatis untuk mendapatkan informasi sentimen yang terkandung dalam suatu kalimat opini, apakah berupa opini positif, netral atau negatif. ${ }^{(14)}$ Untuk melakukan analisis sentimen ada beberapa algoritma yang dapat digunakan, salah satunya dengan metode pengklasifikasian berbasis machine learning, yaitu Naive Bayes Classifier (NBC). NBC merupakan sebuah metode klasifikasi yang berasal dari teorema Bayes dengan menggunakan metode probabilitas dan statistik yaitu memprediksi peluang berdasarkan pengalaman sebelumnya (Teorema Bayes), ciri utamanya adalah asumsi yang sangat kuat (naif) akan 
ketergantungan dari setiap kejadian. ${ }^{(15)}$ Meskipun terdapat penyederhanaan masalah, penggolongan NBC masih memberi tingkat akurasi yang tinggi. ${ }^{(16)}$ Penelitian dengan menggunakan algoritma NBC pernah dilakukan oleh Metwally dkk. (2017) untuk memahami sentimen publik terhadap alat skrining kanker yaitu melalui klasifikasi terhadap 32.847 tweets terkait dengan kolonoskopi, mamografi, atau pap smear menghasilkan akurasi sebesar $80 \%$. ${ }^{(17)}$

Tujuan penelitian ini adalah merancang sistem untuk analisis sentimen terhadap penggunaan antibiotik dari Twitter menggunakan metode Naive Bayes Classifier. Hasil analisis sentimen tersebut dapat menjadi pertimbangan dalam melakukan strategi Komunikasi, Informasi, dan Edukasi (KIE) tentang penggunaan antibiotik yang tepat ke masyarakat.

\section{METODE}

Alur dari penelitian perancangan sistem untuk analisis sentimen terhadap penggunaan antibiotik ini digambarkan sebagai berikut:

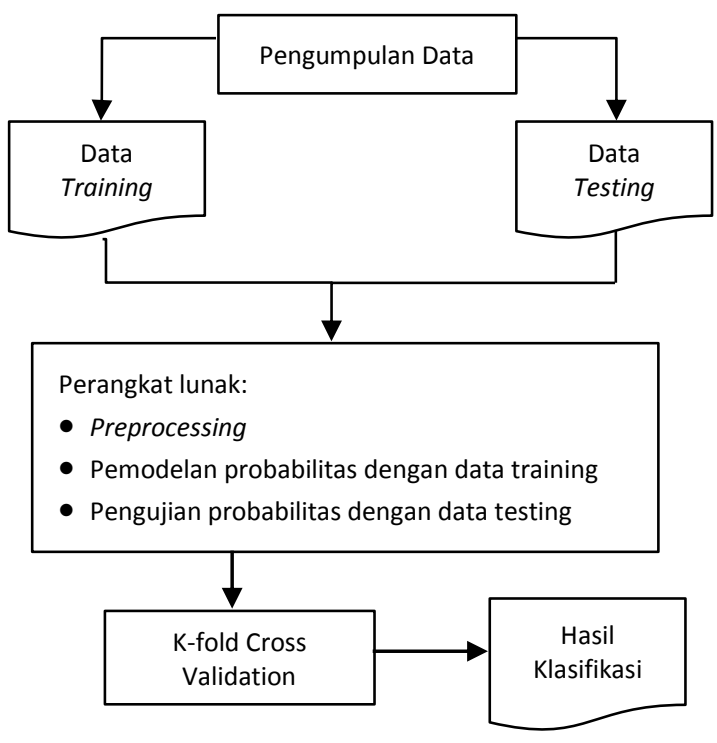

Gambar 1. Alur Penelitian ${ }^{(18)}$

Sedangkan arsitektur sistem yang dibangun adalah sebagai berikut:

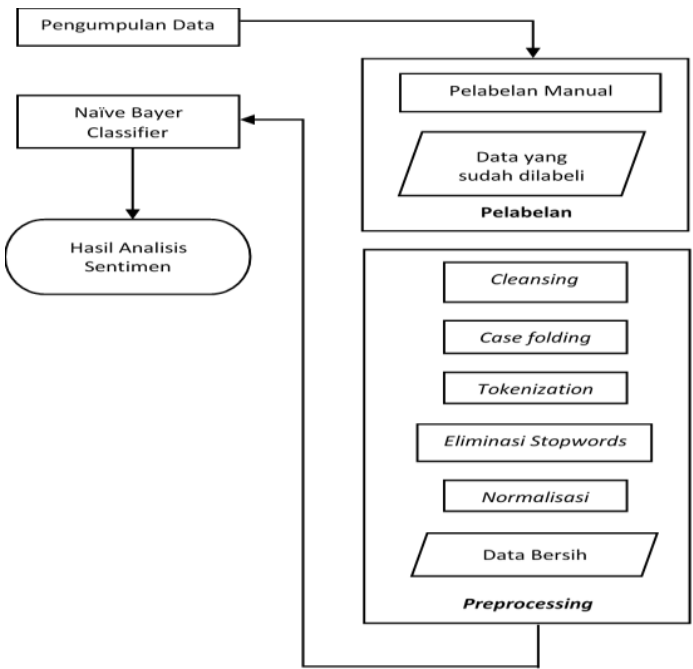

Gambar 2. Arsitektur Sistem

Dalam metode penelitian ini akan menjelaskan langkah-langkah yang dilakukan untuk merancang sistem analisis sentimen Twitter sebagai berikut:

\section{Metode Pengumpulan Data}

Pengumpulan data pada penelitian ini dilakukan dengan cara scraping pada situs www.search.twitter.com berdasarkan keyword yang terkait, yaitu "antibiotik", "penggunaan antibiotik". Proses scraping dilakukan dengan memanfaatkan library Python Tweepy dan Twitter API. Sistem ini akan melakukan pengecekan key consumen dan access token agar dapat mengambil data dari Twitter. Apabila data token terdaftar dalam sistem Twitter maka sistem dapat mengambil data Twitter di wilayah Indonesia. Data tweet bahasa Indonesia dengan query yang dicari. $^{(19)}$

Web Scrapping ini mengambil data kotor secara realtime dari website Twitter, yang selanjutnya akan dipilih menjadi data tweet bersih. Dalam penelitian ini, data diambil pada 22 November 2018 - 28 Februari 2019. Sistem ini menyimpan data tweet kedalam database Mysql. Berikut skema proses pengumpulan data: ${ }^{(20)}$ 


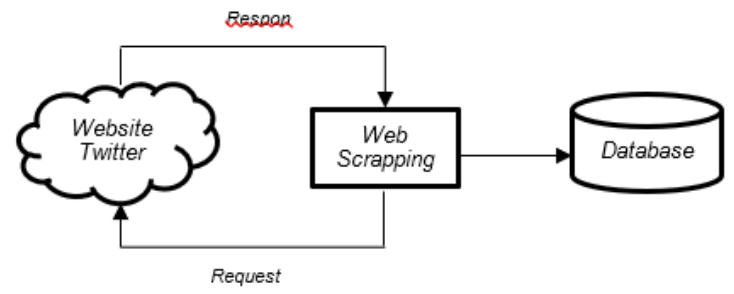

Gambar 3. Proses Pengumpulan Data

\section{Mempersiapkan Data Masukan/Input dan Melakukan Pelabelan Manual}

Data Twitter dipilah (filter). Jumlah data hasil filter 200 data, yang dibagi ke dalam data training $(90 \%)$ dan data testing $(10 \%)$ dipilih secara acak. Data diberi label dengan dua kelas sentimen yaitu sentimen positif untuk komentar atau opini yang bersifat positif dan sentimen negatif untuk komentar atau opini yang bersifat negatif, dengan jumlah data seimbang antara label positif dan label negatif.

\section{Metode Pengolahan Data}

a. Preprocessing

Dalam penelitian ini dilakukan preprocessing dokumen teks, yaitu proses mentransformasikan data tekstual tidak terstruktur menjadi sebuah model data terstruktur. Tujuan dilakukannya preprocessing tweet ini adalah menghilangkan kata yang tidak sesuai penelitian, menyeragamkan bentuk kata dan mengurangi volume kata. Tahapan yang dilakukan pada pra-proses tweet:

i. Cleansing: proses ini bertujuan untuk membersihkan tweet dari kata-kata yang tidak diperlukan untuk mengurangi noise pada proses klasifikasi. Adapun katakata yang dihilangkan antara lain:

- RT atau Retweet

- Hashtag Twitter(\#)

- UsernameTwitter(@username)

- Link URL

- Angka-angka, simbol \% \& ! ? dan tanda baca lain dihilangkan

- Icon atau emoji dihilangkan

ii. Case folding: proses pengubahan semua huruf dalam teks menjadi huruf kecil.

iii. Tokenization: proses ini akan memecah sekumpulan karakter dalam suatu teks ke dalam satuan kata. Karakter selain huruf akan dihilangkan karena dianggap sebagai delimiter (pemisah).

iv. Normalisasi kata:

- Mengubah kata yang telah menjadi singkatan, seperti "bgs" diubah menjadi "bagus". Daftar singkatan gaul dan media sosial diambil dari code.google.com, sinichinet.blogspot.com, cbmagazine.blogspot.com dan ditambahkan berdasarkan hasil pencarian pada data training.

- Huruf yang berulang dalam kata seperti "kereeen" akan dinormalisasi menjadi "keren".

- Kata ulang yang diikuti angka 2 diubah, contohnya oleh2 menjadi oleh-oleh.

v. Eliminasi Stopwords: kata-kata yang terkandung pada daftar stopword akan dihilangkan. Stopword merupakan Pada penelitian ini daftar stopwords umum didapat dari penelitian Tala (2003). (21) dan ditambahkan berdasarkan hasil pencarian pada data training.

Preprocessing menggunakan bahasa pemrograman Python yang menyediakan Library untuk data preprocessing. Tahapan ini menghasilkan fitur (data bersih dan berlabel) yang digunakan sebagai data pembelajaran mesin oleh NBC. Contoh data tweet hasil preprocessing:

\begin{tabular}{|c|c|}
\hline Tweet Asli & Hasil Preprocessing \\
\hline $\begin{array}{l}\text { @LinggarNarisw @inizali } \\
\text { Fg troches harusnya ngga } \\
\text { boleh dibeli sembarangan } \\
\text { setauku deh karena ada } \\
\text { antibiotiknya. Nge } \\
\text { https://t.co/eOly0QdGiB } \\
\end{array}$ & $\begin{array}{l}\text { fg troches harusnya tidak } \\
\text { boleh dibeli } \\
\text { sembarangan setauku } \\
\text { ada antibiotiknya }\end{array}$ \\
\hline $\begin{array}{l}\text { @womanfeeds Kalo mau } \\
\text { minum obat harus pake } \\
\text { resep dokter. Jangan } \\
\text { sembarangan nder apalagi } \\
\text { antibiotic }\end{array}$ & $\begin{array}{l}\text { mau minum obat harus } \\
\text { resep dokter jangan } \\
\text { sembarangan antibiotik }\end{array}$ \\
\hline $\begin{array}{l}\text { @119701_Tapi Gua lagi } \\
\text { minum antibiotik :) } \\
\text { ehehehehehe }\end{array}$ & gua minum antibiotik \\
\hline $\begin{array}{l}\text { @atinahasbo @Ayu_Ratih } \\
\text { Butuh antibiotik antivirus } \\
\text { yg ampuh }\end{array}$ & $\begin{array}{l}\text { butuh antibiotik antivirus } \\
\text { ampuh }\end{array}$ \\
\hline
\end{tabular}


b. Klasifikasi Model

Pemodelan data dibuat dengan tujuan untuk menguji keakuratan prediksi sistem berdasarkan data model yang sudah dibuat. Proses training untuk membangun model probabilitas pada penelitian ini dibutuhkan data training. Selanjutnya dilakukan pengujian model klasifikasi sentimen yang dihasilkan pada proses training dengan menggunakan data tweet baru (data testing). Gambaran umum sistem dapat dilihat pada gambar berikut:

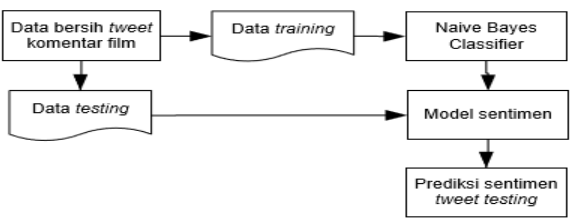

Gambar 4. Pemodelan Data ${ }^{(18)}$

Pada data training, data harus sudah dilabeli terlebih dahulu dan harus melalui proses preprocesing untuk dijadikan input dari penggunaan metode NBC untuk disimpan sebagai model data. Pada proses testing digunakan data baru yang tidak terdapat pada data training. Pada saat data testing dimasukkan kedalam sistem, proses yang akan dilalui adalah penentuan fitur, mengekstrak fitur dan mengklasifikasikannya sesuai dengan model yang sudah dibuat. Sistem akan memberikan hasil klasifikasi sistem yaitu negatif atau positif sesuai dengan model data yang telah dibangun. Pengklasifikasian dengan NBC ini menggunakan library Natural Language ToolKit (NLTK), yang bertujuan untuk mengklasifikasikan tweet sebagai sentimen tweet yang positif atau negatif secara otomatis.

\section{c. Evaluasi Peforma Kualifikasi}

Evaluasi performa model klasifikasi dilakukan dengan mengukur akurasi, presisi, dan recall dari eksperimen yang telah dilakukan. Untuk mengukur akurasi, presisi, dan recall digunakan Confusion Matrix yang menunjukan berbagai prediksi yang benar maupun salah berdasarkan desain klasifikasi yang telah dibuat. Matriks berbentuk NxN dimana $\mathrm{N}$ merupakan jumlah kelas. Dalam penelitian ini dibuat matriks $2 \times 2$. $^{(22)(23)}$

Tabel 1. Confusion Matrix ${ }^{(24)}$

\begin{tabular}{cccc}
\hline & & \multicolumn{2}{c}{ Prediction Class } \\
\cline { 2 - 3 } Actual & Positive & Negative \\
\hline Class & & True & False \\
& & Positive & Negative (FN) \\
\cline { 2 - 4 } & Negative & False & \\
& & Positive & True \\
& & Negative (TN) & \\
\hline
\end{tabular}

Akurasi $=(\mathrm{TP}+\mathrm{TN}) /(\mathrm{TP}+\mathrm{FP}+\mathrm{TN}+\mathrm{FN})$

Presisi $=\mathrm{TP} /(\mathrm{TP}+\mathrm{FP})$

Recall $=\mathrm{TP} /(\mathrm{TP}+\mathrm{FN})$

F-Measure $=2 T P / 2(T P+F P+F N)$

\section{d. K-fold Cross Validation}

$\mathrm{K}$-fold adalah salah satu metode Cross Validation yang populer dengan melipat data sebanyak $\mathrm{K}$ dan mengulangi (iterasi) eksperimennya sebanyak K juga. Pada pengujian ini data yang akan digunakan adalah 200 tweet termasuk data uji yang nantinya akan dibagi menjadi 10 bagian atau $\mathrm{k}=10$ sehingga data yang diperoleh adalah 200 data dibagi menjadi 10 lipatan. Selain itu akan ditentukan mana yang termasuk data training dan mana yang termasuk data testing dengan perbandingan 9:1. Pengujian menggunakan data yang sudah dipartisi akan diulang sebanyak 10 kali $(\mathrm{K}=10)$ dengan posisi data testing berbeda disetiap iterasinya. Misalkan iterasi pertama data tes pada posisi awal, iterasi kedua data testing di posisi kedua begitu seterusnya. ${ }^{(18)}$

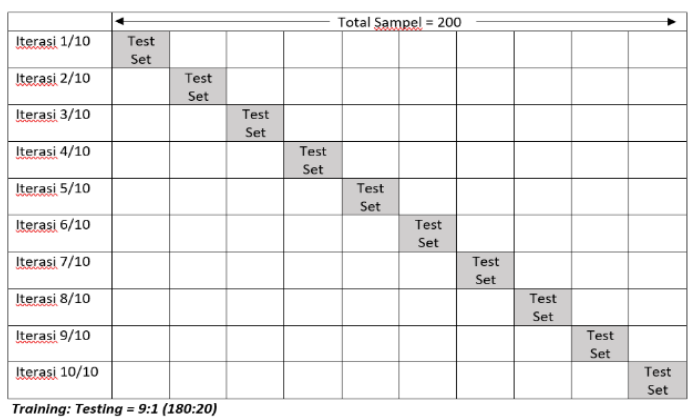

Gambar 5. Ilustrasi 10-fold Cross Validation 


\section{HASIL}

Setelah semua rancangan selesai disusun dan sistem juga telah dibangun, maka tahap berikutnya adalah menggunakan sistem tersebut untuk menghasilkan model probabilitas dari data training, serta menguji akurasi model probabilitas dengan data testing. Untuk pengujian fold ke-1 sampai fold ke-10 jumlah data tes yang dimasukkan adalah 20 tweet dengan posisi data tes seperti digambarkan pada Gambar 5 dan hasilnya dapat dilihat pada Tabel 2 .

Tabel 2. Hasil Pengujian Naïve Bayes Classifier

\begin{tabular}{cccccc}
\hline Fold & $\begin{array}{c}\text { Waktu } \\
(\text { detik })\end{array}$ & $\begin{array}{c}\text { Akurasi } \\
(\%)\end{array}$ & $\begin{array}{c}\text { Presisi } \\
(\%)\end{array}$ & $\begin{array}{c}\text { Recall } \\
(\%)\end{array}$ & $\begin{array}{c}F- \\
\text { Measure } \\
(\%)\end{array}$ \\
\hline 1 & 0,16 & 80 & 83 & 83 & 83 \\
\hline 2 & 0,16 & 75 & 83 & 56 & 67 \\
\hline 3 & 0,16 & 75 & 83 & 56 & 67 \\
\hline 4 & 0,16 & 85 & 89 & 80 & 84 \\
\hline 5 & 0,16 & 77 & 75 & 67 & 71 \\
\hline 6 & 0,17 & 82 & 72 & 88 & 79 \\
\hline 7 & 0,14 & 95 & 100 & 91 & 95 \\
\hline 8 & 0,17 & 95 & 90 & 100 & 95 \\
\hline 9 & 0,16 & 90 & 100 & 83 & 91 \\
\hline 10 & 0,16 & 90 & 80 & 100 & 89 \\
\hline Rata & $\mathbf{0 , 1 6}$ & $\mathbf{8 4}$ & $\mathbf{8 8}$ & $\mathbf{8 1}$ & $\mathbf{8 4}$ \\
-rata & & & & & \\
\hline
\end{tabular}

Dari Tabel 6 dapat dilihat bahwa waktu tercepat yang dibutuhkan sistem untuk memproses data adalah pada saat fold ke-7 dengan waktu 0,14 dan waktu terlama yang dibutuhkan sistem untuk memproses data adalah pada fold ke-6 yaitu 0,17 detik dengan rata-rata waktu yang dibutuhkan dari kelima fold adalah 0,16 detik.

Akurasi yang didapat dari pengujian data tes yang tertinggi pada saat pengujian fold ke-7 dan fold ke-8 yaitu 95\%, dan akurasi terendah pada saat pengujian fold ke-2 dan fold ke-3 yaitu $75 \%$ dengan rata-rata akurasi pengujian kelima fold adalah $84 \%$. Presisi tertinggi pada saat pengujian fold ke-7 dan fold ke-9 yaitu $100 \%$, dan presisi terendah pada saat pengujian fold ke-6 yaitu $72 \%$ dengan rata-rata presisi adalah $88 \%$. Recall tertinggi pada saat pengujian fold ke-8 dan fold ke-10 sebesar $100 \%$, dan recall terendah pada saat pengujian fold ke-2 dan fold ke-3 yaitu $56 \%$ dengan rata hasil recall $81 \%$. Hasil pengujian $f$-measure tertinggi pada saat pengujian fold ke-7 dan fold ke-8 sebesar $95 \%$, dan hasil pengujian $f$-measure terendah pada saat pengujian fold ke-5 sebesar $71 \%$ dengan rata-rata hasil pengujian $f$-measure $84 \%$.

Kemudian dilakukan perancangan prototype sistem analisis sentimen, dan dicoba dengan memasukkan kata kunci "antibiotik" pada periode 27-28 Maret 2019, diperoleh hasil sebagai berikut:
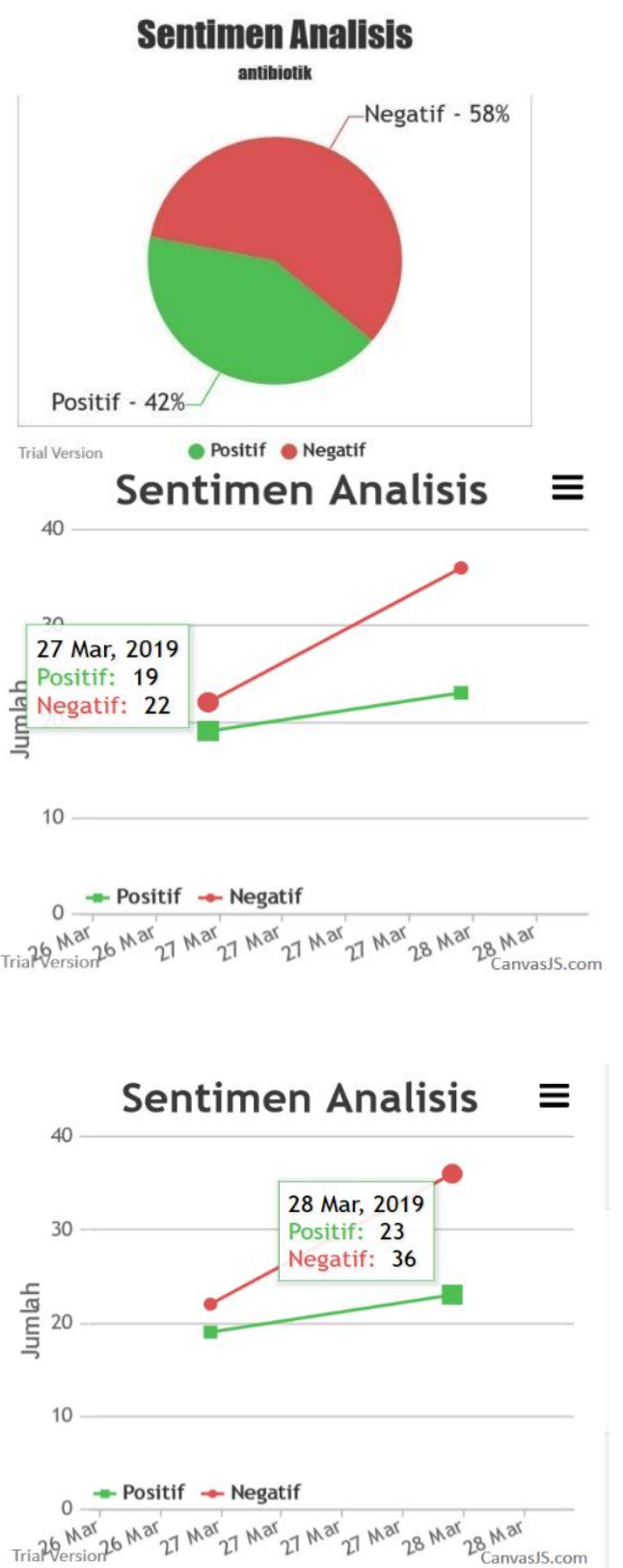
Gambar 6. Tampilan Hasil Analisis Sentimen dengan Kata Kunci "Antibiotik"

\section{PEMBAHASAN}

Dalam penelitian yang dimulai dari pengumpulan data tweet, preprocessing sampai melakukan perhitungan nilai probabilitas menggunakan NBC ini masih terdapat berbagai permasalahan yang membuat sistem dalam penelitian ini belum bekerja secara maksimal, yaitu:

1. Kurangnya data training

Data training yang digunakan pada penelitian ini hanya diperoleh 200 data terkait penggunaan antibiotk di Indonesia, sehingga pada saat data testing yang dimasukkan ada yang tidak dikenali pada data training, maka terdapat hasil prediksi yang tidak sesuai dengan label sebenarnya. Semakin banyak data training yang digunakan maka akan meningkatkan akurasi dan ketepatan sistem dalam mengenali data testing, karena sistem mampu mengenali banyak kalimat dan kosakata yang bervariasi yang dijadikan sebagai pembelajaran oleh sistem.

2. Kendala sistem memahami bahasa manusia

Penggunaan alat otomatis yang dikembangkan ini belum mengenali selukbeluk bahasa manusia seperti isi dari tweet yang mengandung makna sarkasme. Contohnya, orang Indonesia bisa mengucapkan "gila bener" untuk menyatakan kekaguman, namun dengan metode ini, kata kunci tersebut bisa dianggap negatif. Contoh lain, sebagai bentuk sinisme, orang Indonesia dapat berujar "bagoos" padahal tujuannya adalah menyindir. Dalam hal ini, terdapat analisis lebih lanjut yaitu Natural Language Processing (NLP) atau disebut analisis teks, data mining, linguistik komputasional. Dalam artikel yang ditulis oleh Priyandana (2017), disebutkan bahwa NLP merujuk kepada sistem komputer yang melakukan proses bahasa manusia dalam konteks maksud yang disampaikan. NLP mengetahui bahwa gabungan beberapa kata membentuk kalimat, gabungan beberapa kalimat membentuk alinea, dan gabungan beberapa alinea menyampaikan ide. NLP bekerja dengan menganalisis bahasa untuk mengetahui maksud yang ingin disampaikan. Dengan kata lain, dapat dilakukan analisis semantik yaitu studi untuk arti bahasa dan bagaimana bahasa dipahami, sehingga dapat mengekstrak informasi bermanfaat dan relevan dari kumpulan teks dan menganalisis kata-kata asing, termasuk kata kiasan. ${ }^{(25)}$

Dari hasil analisis sentimen dengan memasukkan kata kunci "antibiotik" pada periode 27-28 Maret 2019 sesuai hasil pada Gambar 6 di atas, diperoleh sentimen negatif sebanyak $58 \%$ terhadap penggunaan antibiotik, yang dapat diasumsikan bahwa masyarakat memiliki penolakan untuk menggunakan antibiotik. Hal ini dapat mengindikasikan bahwa sebanyak 58\% masyakat memiliki pengetahuan untuk menghindari penggunaan antibiotik secara sembarangan. Data hasil analisis sentimen tersebut dapat digunakan sebagai data awal untuk dalam melengkapi data hasil pengawasan secara real time dengan cepat untuk melengkapi data survei pelaporan saat ini.

\section{SIMPULAN DAN SARAN}

1. Metode Naïve Bayes Classifier dapat diterapkan sebagai untuk melakukan klasifikasi sentimen analisis terhadap penggunaan antibiotik di Indonesia.

2. Aplikasi sentimen analisis yang dikembangkan dianggap cukup memadai. Hasil uji akurasi klasifikasi yang dilakukan oleh aplikasi menggunakan 10-fold cross validation diperoleh hasil cukup baik ratarata akurasi $84 \%$ dengan rincian nilai presisi $88 \%$, recall $81 \%$ dan $f$-measure $84 \%$.

3. Untuk penelitian selanjutnya, dapat dilakukan dengan memperbanyak data training. Semakin banyak data training akan meningkatkan akurasi dan ketepatan sistem dalam mengenali data testing.

4. Dengan mengetahui tingkat pengetahuan berdasarkan persepsi masyarakat yang diperoleh melalui analisis sentimen di atas, menjadi pertimbangan dalam 
melakukan strategi KIE untuk kampanye penggunaan antibiotik secara rasional.

\section{DAFTAR PUSTAKA}

1. Kementerian Kesehatan. Pasien Cerdas, Bijak Gunakan Antibiotik [Internet]. 2016 [cited 2019 March 29] Available from: http://www.depkes.go.id/article/view/1604 2000002/pasien-cerdas-bijak-gunakanantibiotik.html

2. Kementerian Kesehatan. Peningkatan Pelayanan Kefarmasian Dalam Pengendalian Resistensi Antimikroba "Apoteker Ikut Atasi Masalah Resistensi Antimikroba". ANTIMIKROBA [Internet]. 2017 [cited 2019 March 29]. Available from:

http://www.depkes.go.id/article/view/1711 1500002/peningkatan-pelayanankefarmasian-dalam-pengendalianresistensi-antimikroba-apoteker-ikutatasi-masa.html

3. Badan Pengawas Obat dan Makanan. Sinergi BPOM RI - Pemda Jawa Barat Untuk Cegah Penggunaan Obat dan Resistensi Antibiotika [Internet]. 2018 [cited 2019 March 29]. Available from: https://www.pom.go.id/new/view/more/ber ita/15084/SINERGI-BPOM-RI---PEMDAJAWA-BARAT-UNTUK-CEGAHPENYALAHGUNAAN-OBAT-DANRESISTENSI-ANTIBIOTIKA.html

4. Ventola CL. The Antibiotic Resistance Crisis Part 1: Causes and Threats. 2015;40(4):277-83.

5. Azevedo MM, Pinheiro C, Yaphe J, Baltazar F. Portuguese students' knowledge of antibiotics: a crosssectional study of secondary school and university students in Braga. 2009;6:1-6.

6. Du J, Xu J, Hsing-Yi S, Tao C. Leveraging machine learning-based approaches to assess human papillomavirus vaccination sentiment trends with Twitter data. BMC Med Inform Decis Mak [Internet]. 2017;17. Available from:

https://search.proquest.com/docview/192 5166788 ? accountid $=17242$
7. Cole-Lewis $H$, Varghese $A$, Sanders $A$ Schwarz M, Pugatch J, Augustson E. Assessing Electronic Cigarette-Related Tweets for Sentiment and Content Using Supervised Machine Learning. J Med Internet Res. 2015 Aug;17(8):e208.

8. Chunara R, Andrews JR, Brownstein JS. Social and news media enable estimation of epidemiological patterns early in the 2010 Haitian cholera outbreak. Am J Trop Med Hyg. 2012;86(1):39-45.

9. Culotta A. Detecting influenza outbreaks by analyzing Twitter messages. 2010;(September 2009):1-11. Available from: http://arxiv.org/abs/1007.4748

10. Menon KU. SARS revisited: Managing "outbreaks" with " communications." Ann Acad Med Singapore. 2006;35(5):361-7.

11. Freifeld CC, Brownstein JS, Menone CM, Bao W, Filice R, Kass-Hout T, et al. Digital drug safety surveillance: Monitoring pharmaceutical products in Twitter. Drug Saf. 2014;37(5):343-50.

12. Zhou X, Coiera E, Tsafnat G, Arachi D, Ong MS, Dunn AG. Using social connection information to improve opinion mining: Identifying negative sentiment about HPV vaccines on Twitter. Stud Health Technol Inform. 2015;216(c):7615.

13. Salathé M, Khandelwal S. Assessing vaccination sentiments with online social media: Implications for infectious disease dynamics and control. PLoS Comput Biol. $2011 ; 7(10)$

14. Buntoro GA. Analisis Sentimen Calon Gubernur DKI Jakarta 2017 Di Twitter. Integer J Maret [Internet]. 2016;1(1):32_ 41. Available from: https://www.researchgate.net/profile/Ghul am_Buntoro/publication/316617194_Anali sis_Sentimen_Calon_Gubernur_DKI_Jak arta 2017 Di Twitter/links/5907eee4458 5152d2e9ff992/Analisis-Sentimen-CalonGubernur-DKI-Jakarta-2017-DiTwitter.pdf

15. Rish I. An Empirical Study Of The Naive Bayes Classifier. 
16. Zheng S. Naive Bayes Classifier: A Mapreduce Approach. 2014;(July).

17. Metwally O, Blumberg S, Ladabaum U, Sinha SR. Using Social Media to Characterize Public Sentiment Toward Medical Interventions Commonly Used for Cancer Screening: An Observational Study. J Med Internet Res. 2017 Jun;19(6):e200.

18. Ratnawati F. Implementasi Algoritma Naive Bayes Terhadap Analisis Sentimen Opini Film Pada Twitter. 2018;

19. Ira Zulfa EW. Sentimen Analisis Tweet Berbahasa Indonesia dengan Deep Belief Network. 2017;11(2).

20. Rozi IF, Hamdana EN, Balya M, Alfahmi I. Pengembangan Aplikasi Analisis Sentimen Twitter (Studi Kasus SAMSAT Kota Malang). : 149-54.

21. Tala FZ. A Study of Stemming Eff ects on Information Retrieval in Bahasa Indonesia-Tala.pdf. 2003.

22. Arifin O, Sasongko TB. Analisa Perbandingan Tingkat Performansi Metode Support Vector Machine dan Naïve Bayes Classifier untuk Klasifikasi Jalur Minat SMA. 2018;(2016):67-72.

23. Dj Novakovic J, Veljovi A, lli SS, Zeljko Papi ", Tomovi M. Evaluation of Classification Models in Machine Learning [Internet]. Vol. 7, Theory and Applications of Mathematics \& Computer Science. 2017. p. 39-46. Available from: http://www.uav.ro/stiinte_exacte/journal/in dex.php/TAMCS/article/viewFile/158/126

24. Oye JA. Sentiment Analysis of Norwegian Twitter Messages. 2015;

25. Priyandana A. Analisis Sentimen Media Sosial untuk Dunia Bisnis [Internet]. 2017. [cited 2018 August 7] Available from https://gintong.me/2018/04/03/analisissentimen-media-sosial-untuk-duniabisnis/. 